Again, on p. 304 of the same volume, an entirely wrong meaning is given to a sentence by the failure of the translators to make it clear that "wenn es nothwendig wäre " must refer, not to "fertilisation," but to the " limitation of polar divisions." On p. I36 (vol. ii.) the sense of the original is obscured by the inadequate rendering of "dann" as the enclitic "then." Chaerocampa (for Choerocampa) is found in the original; the translators, however, are responsible for "Cœenogenesis."

But in spite of these and other blemishes of a like nature, the translators are to be congratulated on having performed their difficult task with skill and success, the result being a work which, in its English
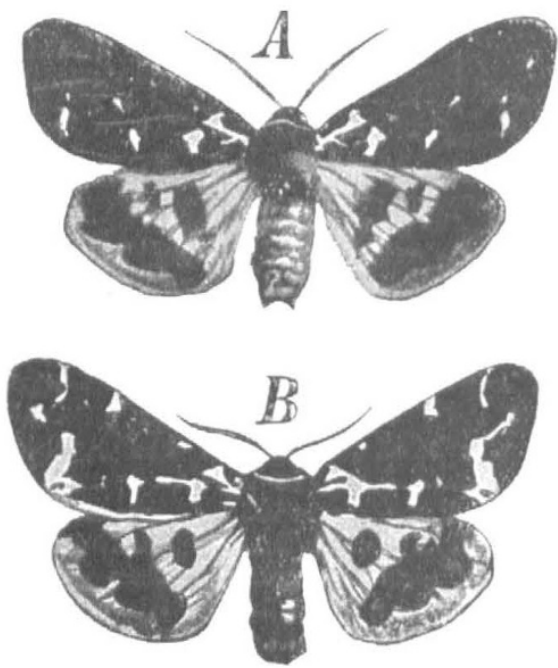

Fig. 2.- $A$, an aberration of Arctia caja, produced by low temperature. $B$, the member of its progeny most divergent from the normal. $B$, though reared at the ordirary temperature, is aberrant in the same direction as its parent. After E. Fischer. From Weismann's "Evolution The sry.' Translated by Prof. and Mrs. Thomson.

no less than in its German dress, will be read with extreme interest and with the greatest sympathy and respect for its indefatigable author. F. A. D.

\section{DR. WILLIAM THOMAS BLANFORD, F.R.S.}

THE tidings of Dr. Blanford's death will be received with sorrow among men of science all over the world. His many-sided accomplishments had given him a notable place among geologists, geographers, palæontologists, and zoologists, and his gentle, kindly, unassuming nature had gained him an abiding place in the affectionate regard of all who came to be associated with him. Born on October 7 , 1832, in London, he early developed a taste for scientific pursuits, and was accordingly sent to the Royal School of Mines, Jermyn Street, where he distinguished himself as a student, under De la Beche, Playfair, Edward Forbes, Ramsay, Smyth, and Percy. From London he passed to the famous mining academy at Freiberg. Having thus obtained an excellent training, he was, in 1855 , appointed to the Geological Survey of India under its founder, Thomas Oldham. For some twenty-seven years he continued to devote his energies to Indian geology, making wide acquaintance with the rocks and scenery of the great Dependency, and enriching the publications of the Survey with maps and descriptive memoirs. Had he chosen to remain longer in the service, he would NO. I861, VOL. 72$]$ soon have been placed at its head; but in 1882 he resolved to retire on the perision which he had well earned, and to establish himself in London. Among the great services which he rendered to science during his stay in India, perhaps the most important was the preparation, in concert with his colleague, $\mathrm{H}$. B. Medlicott, of a "Manual of the Geology of India." This invaluable treatise gave for the first time a succinct general view of the geological structure and history of the whole country. It has taken its place as one of the classic text-books of the science.

While attached to the Indian Survey, Dr. Blanford's proved ability led to his being employed in several missions or expeditions. Thus when, in 1867 , preparations were made in India for the dispatch of an armed force against Theodore of Abyssinia, he was selected as geologist to accompany the Army. The wisdom of this selection was well proved by the excellent volume in which he gave the results of his observations during the march to Magdala and the return to the coast. Again, in 1872, he accompanied the Persian Boundary Commission, and his notes of this journey were embodied in another valuable book.

During his travels in India and beyond it, Dr. Blanford did not confine himself to the study of the rocks, but always kept a keen eye on the wild animals of each region. His published journals showed him to be as capable a zoologist as he was a geologist. Indeed, during the later years of his life his main scientific work lay amidst the fauna of British India, in regard to which his published memoirs were recognised as the chief authority on the subject. His wide experience as a traveller over the surface of the earth likewise enlisted his sympathies with geographical exploration, and made him a valued member of the council of the Royal Geographical Society.

In his writings there is often a suggestiveness or prescience that shows how keen was his insight, how far-reaching his grasp of scientific problems, more especially of those in which questions of zoology and geology were intermingled. Some of his papers in which he unfolded his views on these subjects aro well deserving of attentive study. His address to the geological section of the British Association at the Montreal meeting in 1884 , and his presidential discourses to the Geological Society in 1889 and 1890. may be cited as examples of his characteristic manner of treatment.

Dr. Blanford's high qualities as a man of science were fully recognised by his contemporaries. He was early elected into several of our leading scientific societies, and was chosen as a member of their councils. He received the Wollaston medal of the Geological Society and a Royal medal of the Royal Society. A few years ago, in recognition of his services to Indian science, he was made a Companion of the Order of the Indian Empire. Up to the end he continued to interest himself in the affairs of the societies with which he was connected. For years he had been treasurer of the Geological Society, and he attended the council meetings to within a few weeks before his death. His colleagues at the council board then saw with regret that his health was obviously failing, but they did not anticipate that they were never again to see his familiar face among them. A few weeks ago he was asked by the council of the Royal Society to write for them an obituary notice of his old friend and colleague, Medlicott, who had recently died. He complied with this request, and it proved to be his last piece of work. The printed proofs of his manuscript werf sent to him, but before they could reach him he ha, become too ill to look at them. After a short illness he passed away on the morning of Friday, June 23, 
in the seventy-third year of his age. He was laid to rest on Tuesday last in Highgate Cemetery, every society with which he was associated sending representatives to his funeral, while among the mourners were some of his old colleagues in India.

A. G.

\section{NOTES.}

The Civil List Pensions granted during the year ended March $3 \mathrm{I}$ show more generous recognition of the claims of science than has usually been the case. The list includes the following pensions:-1904, August 8.- Mr. W. F. Denning, in consideration of his services to the science of astronomy, ${ }_{15} \mathrm{ol}$. August 8.-Miss Elizabeth Parker, in recognition of the services rendered to science as an investigator by her late father, $\mathrm{Mr}$. W. Kitchen Parker, F.R.S., Iool. August 8.--Lady Le Neve Foster, in consideration of the services rendered to mining science by her late husband, Sir Clement Le Neve Foster, F.R.S., and of the fact that his death was due to the effects of poisoning by carbonic oxide gas while carrying out his official duties, rool. 1905, January 17.-Dr. J. G. Frazer, in recognition of his literary merits and of his anthropological studies, 20ol. March 22.-The Rev. Lorimer Fison, in recognition of the originality and importance of his researches in Australian and Fijian ethnology, $150 l$. March 22.-Dr. W. Cramond, in consideration of his antiquarian researches, more particularly in connection with the ecclesiastical and burghal history of Scotland, $8 \mathrm{ol}$. March 22.-Miss L. C. Watts and Miss E. S. Watts, in recognition of the services of their late father, Mr. Henry Watts, to chemistry, $75 l$. It is satisfactory to record these tributes of national regard for lives devoted to the advancement of knowledge; and we congratulate the Government upon the great improvement which this year's list shows as regards the acknowledgment of the services rendered to the State by scientific workers.

WE regret to learn that Prof. von Tomek, president of the Imperial Bohemian Academy of Sciences at Prague, died on June $\mathrm{I} 2$ in the eighty-eighth year of his age.

Sir John Wolfe Barry, K.C.B., F.R.S., has been elected to succeed the late Mr. James Mansergh, F.R.S., as chairman of the Engineering Standards Committee.

THE annual conversazione of the Society of Arts will be held in the gardens of the Royal Botanic Society, Regent's Park, on Tuesday next, July 4.

THE International Institute of Sociology has accepted the invitation of the Sociological Society to hold its next congress in London in the summer of rgo6. A general committee has been appointed to promote the success of the congress. Lord Avebury is the chairman of the committee, and Mr. David Mair the secretary for the time being.

THE Guy medal in silver has been awarded by the Royal Statistical Society to Mr. R. Henry Rew for his work in connection with the preparation of the reports of the special committee appointed by the society to investigate the production and consumption of meat and milk in the United Kingdom, and for his paper entitled "Observations on the Production of Meat and Dairy Products."

Among those who lost their lives in the railway disaster at Mentor, Ohio, on June $2 \mathrm{r}$ was Mr. Archibald P. Head, a brilliant young engineer and senior partner in the firm of Messrs. Jeremiah Head and Sons, of Westminster. NO. I 86 I, VOL. 72]
Mr. Head was the author of several valuable papers on mining and metallurgy contributed to the Institution of Civil Engineers, the Iron and Steel Institute, and the Society of Arts.

IT is announced in the Times that the Board of Trade and the Trinity House have concluded a contract with Marconi's Wireless Telegraph Company (Limited) providing for the equipment of lightships with Marconi wireless telegraph installations. This arrangement will enable the lightships to communicate with the shore and with one another by wireless telegraphy for the ordinary purposes of the lightship service, and also to report ships in distress.

A REUTER telegram from Paris reports that an International Congress on Colonial Agriculture was opened there on June 22, Great Britain, Holland, Germany, Italy, Portugal, the United States, Mexico, and Brazil being represented. The members of the congress decided to form an international committee for the study of all questions relating to agricultural science and colonial industries. An organising committee, with headquarters in Paris, under the chairmanship of M. de Lanessan, has been formed.

TOWARD the close of the fourth. International Ornithological Congress, an account of which appeared in our issue of last week (p. 177), a party of members paid a visit on June 20 to Cambridge. They were received by Prof. Newton, who had arranged several exhibits for the benefit of the visitors. These included a case of great auks' eggs and a selection of letters, papers, and books from Prof. Newton's library. A catalogue of these documents and books, some of them belonging to the fifteenth century, was distributed among the visitors, as was a leaflet on Legaut's giant bird by Prof. Newton explaining its origin and species. A pamphlet by Dr. Gadow on the effects of insularity, illustrated by birds of (a) Madagascar and Mascarene Islands, and $(b)$ the Sandwich Islands, was also circulated to explain the exhibits arranged in the lecture room of comparative anatomy. A visit to the museums having been concluded, a dinner was given to Prof. Newton in the hall of Magdalene, after which Dr. Fatio in a cordial speech referred to Prof. Newton as "the father of ornithology." The congress concluded on June 21 with a visit to Flamborough Head.

DR. J. CHARCot gave an account of his expedition to Antarctic regions before the Royal Geographical Society on Monday. The general programme of the expedition was to survey the north-west coast of the Palmer Archipelago (Hoseason, Liége, Brabant, and the Antwerp Islands); to study the south-west entrance to the Gerlache Strait, wintering as far south as was practicable, to make excursions in spring, and in summer to continue the exploration of Graham Land, with the view of elucidating the Bismarck Strait, and follow the coast as far as Alexander I. Land; in a word, to continue the labours of the Gerlache and Nordenskjöld expeditions. The expedition left Buenos Ayres in the Français (245 tons) on December 23, 1903, reached Smith Island (South Shetlands) on February I, 1904, and after coasting for a few weeks was compelled by ice to return to Wandel Island, where it wintered. The temperature varied much and suddenly; the lowest was $-30^{\circ} .4 \mathrm{~F}$, but a rise from $-22^{\circ} \mathrm{F}$. to $+26^{\circ} \cdot 6 \mathrm{~F}$. in a few hours was not uncommon, and was always followed by violent gales from the north-east, which broke up the ice between Wandel and Hovgaard Islands, and so prevented any move being made, in spite of many efforts. In December, 1904, a channel was made, and the Français returned to Wincke Island, which had been visited before 